Quarterly Journal of the Geological Society

\title{
On the Discovery of a Palæolithic Human Skull and Mandible in a Flint-bearing Gravel overlying the Wealden (Hastings Beds) at Piltdown, Fletching (Sussex)
}

Charles Dawson and Arthur Smith Woodward Quarterly Journal of the Geological Society 1913, v.69; p117-123.

doi: 10.1144/GSL.JGS.1913.069.01-04.10

$\begin{array}{ll}\begin{array}{l}\text { Email alerting } \\ \text { service }\end{array} & \begin{array}{l}\text { click here to receive free } \\ \text { e-mail alerts when new articles } \\ \text { cite this article }\end{array} \\ \begin{array}{l}\text { Permission } \\ \text { request }\end{array} & \begin{array}{l}\text { click here to seek permission } \\ \text { to re-use all or part of this } \\ \text { article }\end{array} \\ \text { Subscribe } & \begin{array}{l}\text { click here to subscribe to } \\ \text { Quarterly Journal of the } \\ \text { Geological Society or the Lyell } \\ \text { Collection }\end{array}\end{array}$

\section{Notes}

(C) The Geological Society of London 2014

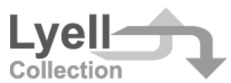


Vol. 69.] Discovery of a paleolithic hUMaN SKULL in sUssex. 117

8. On the Discovery of a Palemolithic Human Skoll and Mandible in a Flint-bearing Gratel overiting the Wealden (Hastings Beds) at Piltdown, Fletching (Sussex). By Charles Dawson, F.S.A., F.G.S., and ARTHUR SMITH WoodwaRd, LL.D., F.R.S., Sec.G.S. With an Appendix by Prof. Grafton Eltiot Sirte, M.A., M.D., F.R.S. (Read December 18th, 1912.)

\section{Geology and Fuint-Implenents. [C. D.]}

\section{[Plates XV-XVII.]}

Severat years ago I was walking along a farm-road close to Piltdown Common, Fletching (Sussex), when I noticed that the road had been mended with some peculiar brown flints not usual in the district. On enquiry $I$ was astonished to learn that they were dug from a gravel-bed on the farm, and shortly afterwards I visited the place, where two labourers were at work digging the gravel for small repairs to the roads. As this excavation was situated about 4 miles north of the limit where the occurrence of flints overlying the Wealden strata is resorded, I was much interested, and made a close examination of the bed. I asked the workmen if they had found bones or other fossils there. As they did not appear to have noticed anything of the sort, I urged them to preserve anything that they might find. Opon one of my subsequent visits to the pit, one of the men handed to me a small portion of an unusually thick human parietal bone. I immediately made a search, but could find nothing more, nor had the men noticed anything else. The bed is full of tabular pieces of ironstone closely resembling this piece of skull in colour and thickness ; and, although I made many subsequent searches, I could not hear of any further find nor discover anything - in fact, the bed soemed to be quite unfossiliferous.

It was not until some years later, in the autumn of 1911 , on a visit to the spot, that I picked up, among the rain-washed spoilheaps of the gravel-pit, another and larger piece belonging to the frontal region of the same skull, including a portion of the left superciliary ridge. As I had examined a cast of the Heidelberg jaw, it occurred to me that the proportions of this skull were similar to those of that specimen. I accordingly took it to Dr. A. Smith Woodward at the British Museum (Natural History) for comparison and determination. He was immediately impressed with the importance of the discovery, and we decided to employ labour and to make a systematic search among the spoil-heaps and gravel, as soon as the floods had abated; for the gravel-pit is more or less under water during five or six months of the year. We accordingly gare up as much time as we could spare since last spring (1912), and completely turned over and sifted what spoil- 
material remained; we also dug up and sifted such portions of the gravel as had been left undisturbed by the workmen. ${ }^{1}$

Fig. 1.-Plan of the basin of the Sussex Ouse, showing the distribution of iron-stained fints and flint-bearing gravels.

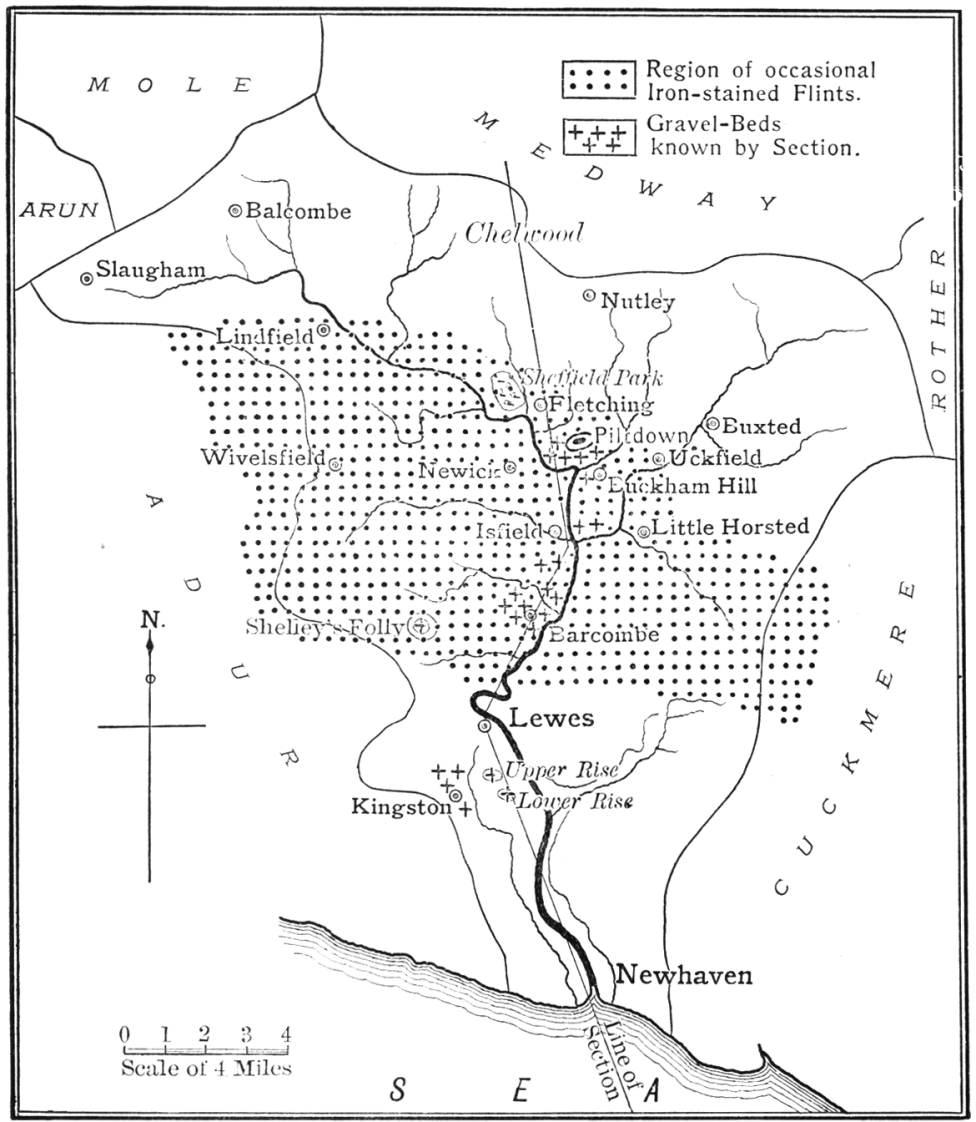

For many years the harder layers of this gravel-bed have been intermittently worked for farm-road material, as shown by old excavations which are now overgrown, but are traceable over the adjoining fields; and there is known to exist a grarel-bed of appreciable thickness extending over several neighbouring acres. Where the beds have been naturally denuded, a large number of

1 These excavations were undertaken with the kind consent of the Lord of the Manor, Mr. G. M. Maryon-Wilson, and of Mr. Robert Kenward, tenant of the farm, to whom the Authors wish to record their grateful acknowledgments. 
the brown and red flints and the ironstone gravel are to be seen overlying the plough-lands in all directions.

At Piltdown the gravel-bed occurs beneath a few inches of the surface-soil, and varies in thickness from 3 to 5 feet; it is deposited upon an uneven bottom, consisting of hard yellow sandstone of the 'lunbridge Wells Sands (Hastings Beds). It is composed for the most part of dark-brown Wealden ironstone pebbles, but is mixed, to the extent of about a sixth of the mass, with angular brown flints, a large proportion of which are tabular in form. ${ }^{1}$ Occasional cherts and quartzite pebbles also occur, but there are no recognizable Eocene pebbles. ${ }^{2}$ The flints vary from 6 or 7 inches in length by 3 or 4 inches in width, down to a very fine gravel or sand. Portions of the bed are rather finely stratified, and the materials are usually cemented together by iron oxide, so that a pick is often needed to dislodge portions-more especially at one particular horizon near the base. It is in this last-mentioned stratum that all the fossil bones and teeth discovered in situ by us have occurred. The stratum is easily distinguished in the appended photograph (Pl. XV) by being of the darkest shade and just above the bed-rock.

The gravel is situated on a well-defined plateau of large area, lying above the 100-foot contour-line, averaging about 120 feet at Piltdown, and lies about 80 feet above the level of the main stream of the Ouse. The river has cut through the plateau, both with its main stream and its principal branch, which is called the Uckfield River.

Speaking generally, the remains of this platean, of which that at Piltdown is merely a part, can in places be traced along a line drawn through Lindfield, Sheffield Park, Buckham Hill, Uckfield, and Little Horsted and southwards, broadening outwards towards the Chalk Fiscarpment. In fact, the whole country lying between the base of the Wealden Anticline and the Chalk Escarpment presents the appearance of one large low platean or former baselevel plane dissected by the Ouse and its tributary streams.

Remnants of the flint-grarels and drifts constantly occur above the 100-foot contour-line, and upon the slopes, down which they are trailing towards the river and streams.

These flint-bearing gravels and drifts have not been mapped or otherwise recorded before in the Ouse Valley, north of the boundary between the Wealden Clay and the Hastings Beds, which runs immediately sonth of Isfield. Up to the latter point they are

1 There is a tendency among these tabular flints to weather into a prismatic or polyhedral form. One specimen shows a column 2 inches in length. The prismatic structure is well shown in figs. 2, 6, 7, \& 9 of Pl. XVII. Most of the nodular flints, formerly existing, appear to have disintegrated.

2 Dr. J. V. Elsden writes that Tertiary pebbles are found in the Ouse gravels on the south near Lewes. Eocene pebbles occur in a thin bed east of the Race Stand, on the hill above Lewes; and a similar band is to be seen about 15 feet down the cliff, near the Coastguard Station at Newharen. See Q. J. G. S. vol. xliii (1887) pp. 646-47. 


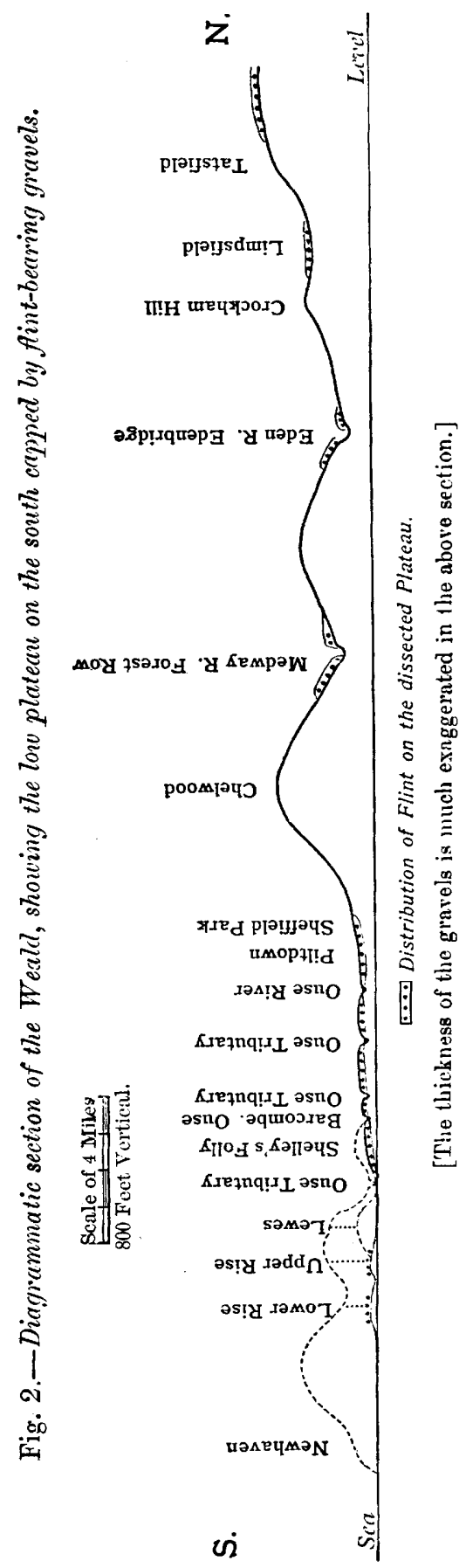

common, and they have been described by Mautell, 'Topley, ${ }^{2}$ and Dr. Elsden ${ }^{3}$; but both Topley and those who hare followed him use almosi the same words, namely, that

'on entering the Hastings Beds country, flints no longer occur either on the surface, or in the river-gravel.'

Howerer, in the Tunbridge Wells Sands(Hastings Beds), out of a thousand fields of which I have a record, that have all been thrice tested by means of boreholes to the depth of 3 feet, fifty fields or more furnish abundant evidence of the presence of these brown and red flints. They are present over the Wadhurst Clay between Isfield and Buckham Hill, but the boundary of this stratum is faulted. I have only found them to occur as small fragments, and seldom on the older Wealden Beds of the higher levels within the Ouse watershed.

The field-borings go to show that in the greater part of the area over which the flint is distributed, the gravel seldom occurs within 3 feet of the surface in beds of appreciable thickness ; but trial-borings along the slopes reveal considerable deposits of gravel, containing small

1 'Geology of the South-East of England '1833, p. 28.

2 "Geology of" the Weald" Mem. Geol. Surv. 1875, pp. 202, 273, 287-88, 292.

3 Q. J. G. S. vol. xliii (1887) p. 646 .

+ See also A. J. Jukes-Browne, 'Building of the British Isles' 3rd ed. (1911) p. 426; and A.C. Ramsay, 'Physical Geology, \&c.' 5 th ed. (1878) p. 344 . 
Vol. 69.] DISCOVERY OF A PALAOLITHIC HUMAN SKULL IN SUSSEx. 12l

fragments of iron-stained flint, 6 feet and more beneath the surface.

Considering the amount of material excavated and sifted by us, the specimens discovered were numerically small and localized.

Apparently the whole or greater portion of the human skull had been shattered by the workmen, who had thrown away the pieces unnoticed. Of these we recovered, from the spoil-heaps, as many fragments as possible. In a somewhat deeper depression of the undisturbed gravel I found the right half of a human mandible. So far as I could judge, guiding myself by the position of a tree 3 or 4 yards away, the spot was identical with that upon which the men were at work when the first portion of the cranium was found several years ago. Dr. Woodward also dug up a small portion of the nccipital bone of the skull from within a yard of the point where the jaw was discorered, and at precisely the same level. The jaw appeared to have been broken at the symphysis and abraded, perhaps when it lay fixed in the gravel, and before its complete deposition. The fragments of cranium show little or no sign of rolling or other abrasion, save an incision at the back of the parietal, probably caused by a workman's pick.

$A$ small fragment of the skull has been weighed and tested by Mr. S. A. Woodhead, M.Sc., F.I.C., Public Analyst for East Sussex \& Hove, and Agricultural Analyst for East Sussex. He reports that the specific gravity of the bone (powdered) is 2.115 (water at $5^{\circ} \mathrm{C}$. as standard). No gelatine or organic matter is present. There is a large proportion of phosphates (originally present in the bone) and a considerable proportion of iron. Silica is absent.

Besides the human remains, we found two small broken pieces of a molar tooth of a rather early Pliocene type of elephant, ${ }^{1}$ also a nuch-rolled cusp of a molar of Mastodon, portions of two teeth of Hippopotamus, and two molar teeth of a Pleistocene bearer. In the adjacent field to the west, on the surface close to the hedge dividing it from the gravel-bed, we found portions of a red deer's antler and the tooth of a Pleistocene horse. These may have been thrown away by the workmen, or may have been turned up by a plough which traversed the upper strata of the continuation of this gravel-bed. Among the fragments of bone found in the spoil-heaps occurred part of a deer's metatarsal, split longitudinally. This bone bears upon its surface certain small cuts and scratches, which appear to have been made by man. All the specimens are highly mineralized with iron oxide.

1 It is stated by R. A. C. Godwin-Austen (Q. J. G. S. vol. vii, 1851, p. 288) and E. Dixon ('Geology of Sussex' 2nd ed. 1878, p. 110, n.) that remains of 'the large mammalin, including teeth of' elephants, were found in the gravels at Barcombe, 6 or 7 miles soutle of Piltdown. It is not known to what genera or species these belonged; but, as they are referred to as "the Asiatic Elephant,' they were probably the true form of Elephas and not Mastodon, though it is possib!e that some may have belonged to the species akin to E. meridionalis. Specimens from tlis bed are not known to have been preserred, but they probably belonged to the Pleistocene age. 


\section{Flint-Implements.}

The brown flints appear to be in every way similar to the plateau flints of Ightham (Kent), and generally to those of the High-Plateau gravels of the North and South Downs. There is the same appearance of tabular and prismatic structure, 'frost fractures,' thick iron-stained patina, and often the same tendency to assume the well-known 'Eolithic' forms (Pl. XVII). There also occur more occasionally certain brilliantly-coloured iron-red flints, presumably more highly oxidized than the prevailing flints, which are of a brown colour. Among the flints we found sereral uudoubted flint-implements,' besides numerous 'Eoliths.' The workmanship of the former (Pl. XVI) is similar to that of the Chellean or pre-Chellean stage ${ }^{2}$; but in the majority of the Piltdown specimens the work appears chiefly on one face of the implements. They have been very slightly rolled or worn, and, although ironstained, their patina is not so strong and thick as that of the other flints in the bed. Their form is thick, and the flaking is broad and sparing, the original 'bark,' or surface, of the flint frequently remaining at the grasp, the whole implement thus having a very rude and massive form. Some of them were found on the surface of a ploughed field adjacent to the gravel-bed, which is also strewn with brown and red flints; but, on the surface of the neighbouring plough-lands there occur, in places, flint-implements of various ages, all more or less stained with the iron which abounds in this part of the Weald. In our plates we have confined ourselves to the representation of flints found in the gravel-pit at Piltdown.

As to the 'Eoliths,' 3 it is necessary to speak of them with due reserve and caution. 'The commonest types belong to the 'borer' and 'hollow-scraper' forms. They occur both in the gravel-bed and on the surface of the plough-lands, and are found in both i rolled and an unrolled (or very slightly rolled) condition. Pl. XVII

1 Father P. Teilhard, S.J., who accompanied us on one occasion, discovererl one of the implements (P1. XVI, fig. 2) in situ in the middle stratum of the gravel-bed, also a portion of the tooth of a Pliocene elephant (Pl. XXI, fig. $\bullet$ ) from the lowest bed.

${ }^{2}$ Implements of this stage are difficult to classify with certainty, owing to the rudeness of their workinanship. The Pildown specimens una be conipared with an example from Chelles, figured in Piette's ' L'Art pendant I'Âge du Renne'p. 36. They resemble certain rude implements occasionally found on the surface of the Clalk Downs near Lewes, which are not iron-stained.

3 The flints, which so nearly resemble those of the plateau gravels of tine North Downs, occur sporadically over the South Downs and over many of the older rocks of the Weald. They have lately been discovered in the fields close to the signal-station at Fairlight Down on the summit of the Wealden Anticline (base of the Ashdown Beds and top of the Fairlight Clay) by Mr. W. Ruskin Butterfield, of the Hastings Museum. They occur in the surface-deposits only, mingled with Neolithic implements and certain ironstained implements which Mr. Reginald Smith, F.S.A., identifies with the early cave types. The last-named are not rolled. Mr. Lewis Abbott, F.G.S., bas given considerable attention to this subject, and possesses a large series of implements which we inay hope will some day be described in cletail. 
illustrates both of these classes of 'Eóliths.' Whether natural or artificial, the fractures appear to have been largely governed by the prismatic structure of the flint. Both the rolled and the unrolled 'Eoliths' are deeply stained and patinated, but the former to a much greater extent than the latter.

\section{Conclusions.}

In conclusion, we may briefly consider the age of the human skull and mandible.

It is clear that this stratified gravel at Piltdown is of Pleistocene age, but that it contains, in its lowest stratum, animal remains derived from some destroyed Pliocene deposit probably situated not far away, and cousisting of worn and broken fragments. These were mixed with fragments of early Pleistocene mammalia in a better state of preservation, and both forms were associated with the human skull and mandible, which show no more wear and tear than they might have received in situ. Associated with these animal remains are 'Eoliths,' both in a rolled and an unrolled condition; the former are doubtless derived from an older drift, and the latter in their present form are of the age of the existing deposit. In the same bed, in only a very slightly higher stratum, occurred a flint-implement (Pl. XVI, fig. 2), the workmanship of which resembles that of implements found at Chelles; and among the spoil-heaps were found others of a similar, though perhaps earlier, stage.

From these facts it appears probable that the skull and mandible cannot safely be described as being of earlier date than the first half of the Ploistocene Epoch. The individual probably lived during a warm cycle in that age.

\section{EXPLANATION OF PLATES XV-XVII.}

\section{Plate XV.}

Flint-bearing gravel-bed overlying the Tunbridge Wells Sands (Hastings Beds) at Piltdown, Fletching, Sussex. The darkest stratum resting on the berl-rock in the section is that from which the skull and mandible were obtained.

\section{Plate XVI.}

Fig. 1. Palaeolithic implement, well worked on one face (1); a simple flake on the other face $(1 a)$; twisted in edge-view $(1 b)$; and thickest at the broader end $(1 c)$. Natural size.

2. Palæolithic implement, worked on one face (2); simply flaked on the other face $(2 a)$; seen in edge-view $(2 b)$ to be relatively thick at the broader end, with remains of the flint-nodule from which it was made. Natural size.

3. Palicolithic implement, showing much of the outer surface of the original flint-nodule on its well-flaked face (3); simply flaked on the other lace $(3 a)$; and very unsymmetrical in basal view $(3 b)$. Half of the natural size.

[All the abore implements are iron-stained.] . 
Downloaded from http://jgslegacy.lyellcollection.org/ at New Mexico State

University on September 7, 2014



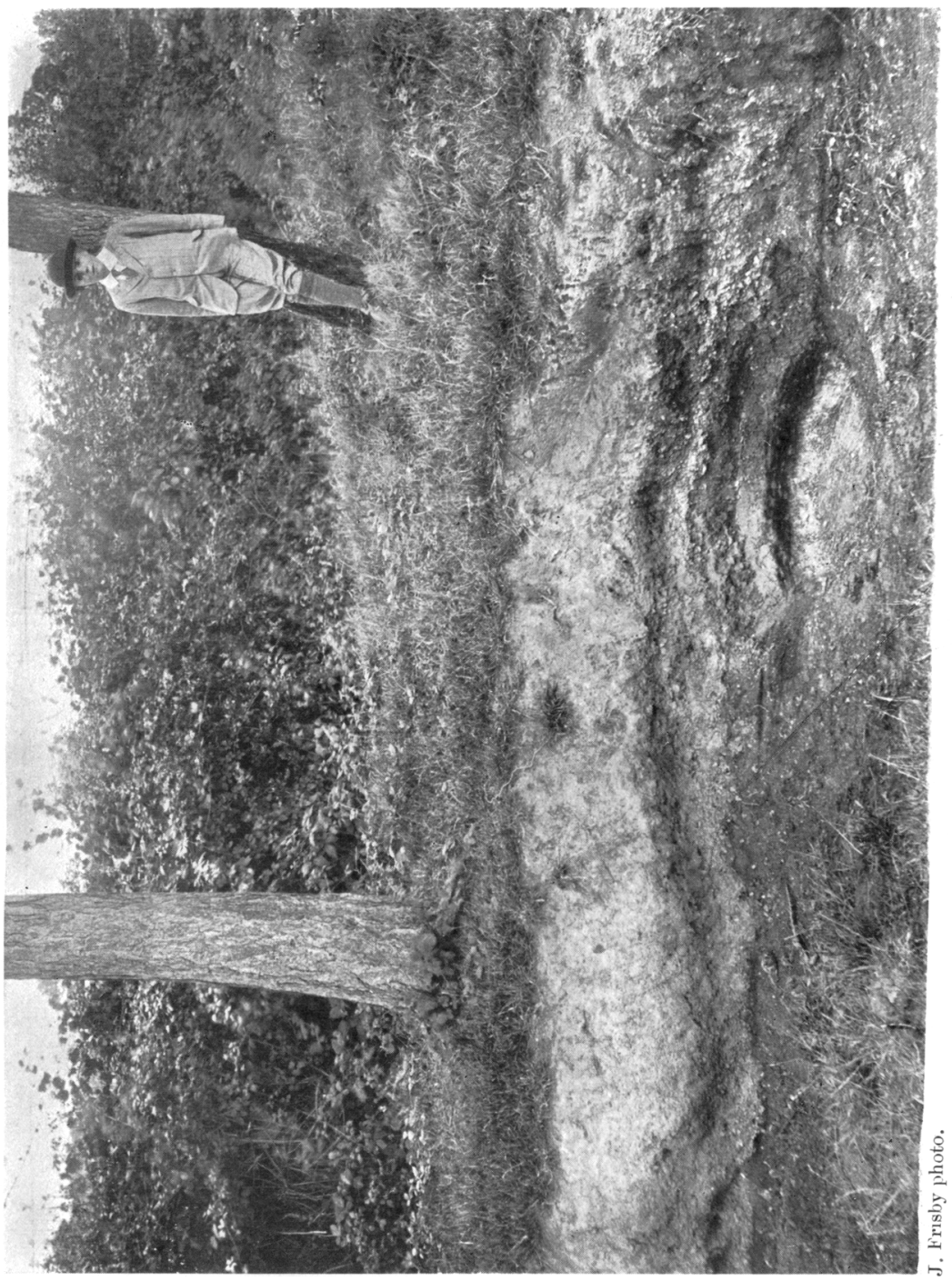

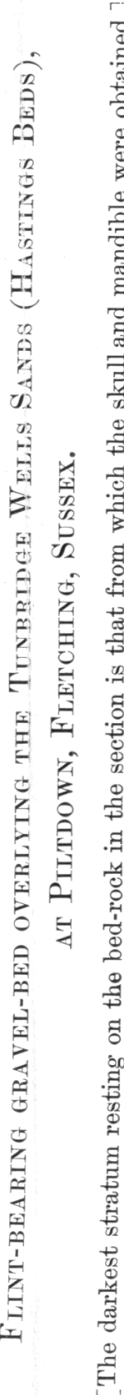




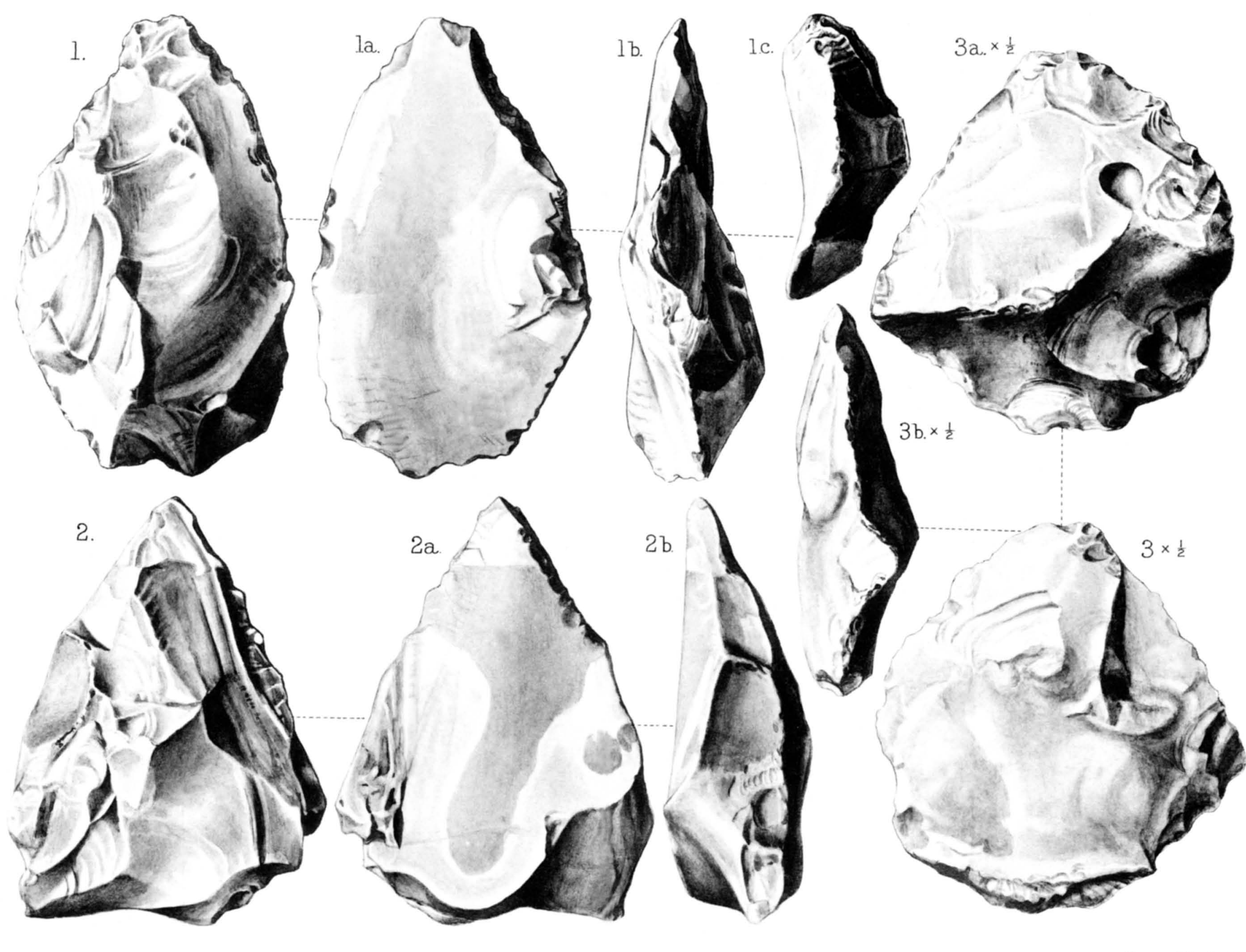



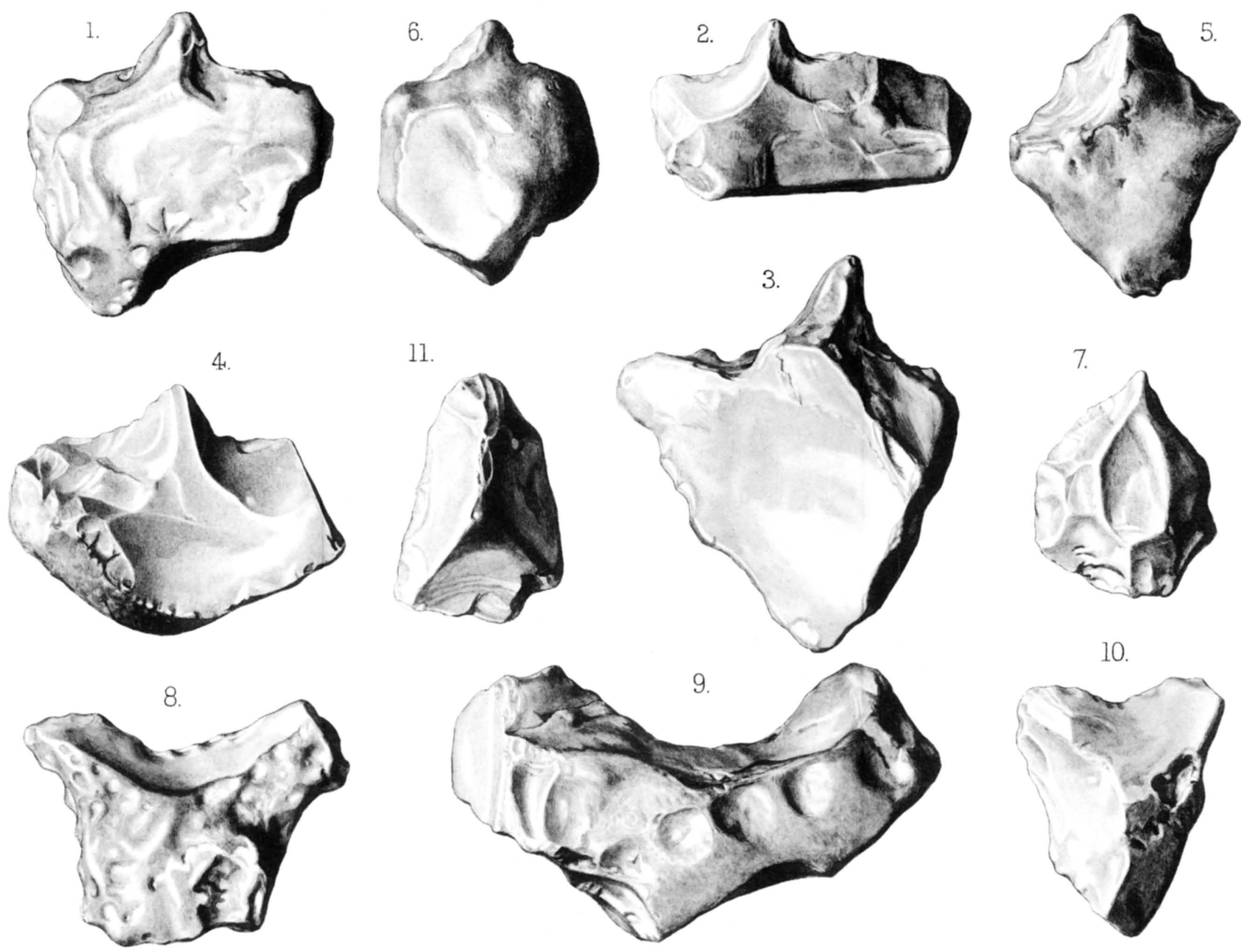

"EOLITHS" from Piltdown (Sussex). 